\title{
Antioxidant defenses and lipid peroxidation in two Lithodes species from South Atlantic during summer
}

\author{
Defensas antioxidantes y peroxidación de lípidos en dos especies \\ de Lithodes del Atlántico Sur durante el verano

\section{Carolina Romero ${ }^{1}$, Natasha Schvezov ${ }^{1}$, M. Paula Sotelano ${ }^{1}$, Mariano J. Diez ${ }^{1}$, Olga Florentin ${ }^{1}$, Federico Tapella ${ }^{1}$ and Gustavo A. Lovrich ${ }^{1}$}

\begin{abstract}
${ }^{1}$ Centro Austral de Investigaciones Científicas (CADIC) - CONICET, Houssay 200, V9410CAB Ushuaia, Tierra del Fuego, Argentina. carofrau@gmail.com.

Resumen.- En el sur de Sudamérica Lithodes santolla y L. confundens representan las especies de centollas más apreciadas, debido a sus altos rendimientos y aceptación en los mercados. Desde un punto de vista fisiológico, las especies reactivas del oxígeno (ROS) son continuamente producidas como productos de la respiración celular. Estos ROS se transforman en metabolitos menos tóxicos por medio de enzimas antioxidantes. El objetivo fue determinar en Lithodes santolla (del Golfo San Jorge) y L. confundens (de la costa atlántica de Tierra del Fuego) el nivel de base de la actividad enzimática antioxidante y los niveles de peroxidación de lípidos. Las enzimas catalasa (CAT) y glutatión-S-transferasa (GST) y la peroxidación de lípidos se midieron en branquias, músculo y hepatopáncreas. Ambas especies mostraron actividad enzimática antioxidante, mientras que las branquias presentaron la mayor actividad enzimática de CAT. La actividad de CAT y GST fue mayor en L. confundens en el músculo y branquias respectivamente, comparado con L. santolla; mientras que la peroxidación de lípidos fue menor en ambos órganos. Estas diferencias entre ambas especies sugieren que $L$. confundens sería más eficiente ante situaciones de estrés oxidativo, debido probablemente a los periodos de anoxia que experimenta durante las bajas mareas de primavera. Además, estas diferencias podrían ser atribuidas a características intrínsecas de adaptación de cada especie de centolla y/o a condiciones ambientales de cada área de estudio en particular. Parámetros como CAT, GST y peroxidación de lípidos podrían proponerse como biomarcadores de estrés oxidativo en Lithodes santolla y L. confundens.
\end{abstract}

Palabras clave: Actividad enzimática, especies reactivas del oxígeno, centollas

\begin{abstract}
In Southern South America Lithodes santolla and L. confundens are the most valuable king crabs species, specially due to their high yields and their high acceptance in the markets. From a physiological point of view, reactive oxygen species (ROS) are continuously produced as by-products of cell respiration. These ROS are transformed into less toxic metabolites by antioxidant enzymes. The aim of the present study was to determine in Lithodes santolla (from San Jorge Gulf) and L. confundens (from Atlantic coast of Tierra del Fuego) the baseline status of both antioxidant enzyme activity and lipid peroxidation levels. Activities of catalase (CAT), glutathione-S-transferase (GST), as well as lipid peroxidation were measured in the muscle, gills and hepatopancreas. Both species showed antioxidant enzyme activities, and the gills were the organs with the highest CAT enzyme activities. CAT and GST activities were higher in muscle and gills, respectively, in $L$. confundens compared with L. santolla, whereas lipid peroxidation was low in both organs. These differences between both species suggest that $L$. confundens is more capable to afford oxidative stress than $L$. santolla, which may be a response to the common occurrence of $L$. confundens at the intertidal during the spring low tides. Differences in the analysed parameters could be attributed to intrinsic adaptation features of each king crab species and/or to environmental conditions of each particular study area. Furthermore, our results showed that parameters as CAT, GST and lipid peroxidation could be proposed as biomarkers of oxidative stress in Lithodes santolla and L. confundens.
\end{abstract}

Key words: Enzymatic activity, reactive oxygen species, king crabs

\section{INTRODUCTION}

Among the 12 species of Lithodidae that inhabit the Atlantic and Pacific waters of Southern South America, the southern king crabs (SKC) Lithodes santolla and $L$. confundens represent the most valuable species due to their high yields and their high acceptance in the markets.
Although both species are commonly misidentified because of their morphological similarity, they can be distinguished by the carapace spinulation pattern (Macpherson 1988) and their distribution only overlaps in the northern continental slope of Argentina, $c a ., 37^{\circ} \mathrm{S}$ 
(Sotelano et al. 2013). Lithodes santolla occurs widely around the southern South America; at the Pacific coast, it occurs south from Chiloé Island $\left(42^{\circ} \mathrm{S} 74^{\circ} \mathrm{W}\right)$ to Cape Horn $\left(55^{\circ} \mathrm{S} 67^{\circ} \mathrm{W}\right)$, including the Straits of Magellan $\left(53^{\circ} \mathrm{S}\right.$ $70^{\circ} \mathrm{W}$ ) and fjords around Tierra del Fuego (Macpherson 1988). Whereas, in the southern Atlantic waters $L$. santolla presents a disjoint distribution: mainly in the San Jorge Gulf $\left(46^{\circ} \mathrm{S} 66^{\circ} \mathrm{W}\right)$ and in the Beagle Channel $\left(54^{\circ} \mathrm{S} 68^{\circ} \mathrm{W}\right)$, where fisheries develop (Lovrich \& Tapella 2013). In contrast, L. confundens has only been found in the Burdwood Bank (54 $\left.{ }^{\circ} \mathrm{S} 59^{\circ} \mathrm{W}\right)$ and mainly in coastal waters of Southern Patagonia (50-56 ${ }^{\circ} \mathrm{S}, 67-69^{\circ} \mathrm{W}$ ) (Macpherson 1988, Lovrich et al. 2002 ).

The SKC fisheries around Tierra del Fuego began with the extraction of Lithodes santolla in Chile during in the 1930's and in the 1960's in Argentina (Vinuesa 1991), and reached their maximum yields of $c a ., 3,500$ annual tonnes during the mid 1980's. However, the constant reduction of landings promoted the extraction of the stone crab Paralomis granulosa with less commercial interest and until then considered as by catch, and also the commercial exploitation of northern stocks of SKC, as in the San Jorge Gulf. In the Southwestern Atlantic south to $40^{\circ} \mathrm{S} L$. santolla and $L$. confundens fisheries developed at different degree, and during the recent years the fishery of $L$. santolla based in Comodoro Rivadavia has expanded rapidly from the incorporation of larger fishing vessels known as crabbers.

Although most of the oxygen consumed by aerobic organisms undergoes complete reduction by cytochrome oxidase to form water, various enzymatic and nonenzymatic reactions inside cells result in a partial reduction of oxygen (Hermes-Lima 2004). Thus, reactive oxygen species (ROS) as superoxide anion radical $\left(\mathrm{O}_{2}^{-{ }^{-}}\right)$, hydrogen peroxide $\left(\mathrm{H}_{2} \mathrm{O}_{2}\right)$ and the hydroxyl radical ( $\mathrm{HO}$ ) are continuously produced as by-products of cell respiration. These ROS are transformed into less toxic metabolites by antioxidant enzymes (Halliwell \& Gutteridge 1999). Aerobic organisms possess a baseline status of antioxidant systems to assure the maintenance of a balance between production and removal of endogenous ROS and other pro-oxidants (Correia et al. 2003).

The enzymatic antioxidant defenses are represented by enzymes like catalase (CAT), superoxide dismutase (SOD) and glutathione peroxidase (GPx) (Hermes-Lima 2004). Other enzymes, like glutathione reductase and glutathione-S-transferase (GST) aid in protective and repair processes (Leaver \& George 1998). The variations in tissue of aerobic metabolism should impose variations in ROS generation; these fluctuations could be associated with variations in the antioxidant defense systems and cause oxidative stress if the defenses are overwhelmed by ROS production (Maciel et al. 2004).

Other parameter indicative of animal stress is the lipid peroxidation, which indicates lipid membrane damage as a consequence of exposure to ROS and insufficient antioxidant defenses (Antó et al. 2009). Furthermore, endogenous variables like nutritional status, age, sex, growth and reproduction influence the peroxidation status of organisms (see Dutra et al. 2008). Lipid peroxidation is also considered as the main process responsible for the loss of quality in meat products, besides microbiological deterioration (Eburne \& Prentice 1996).

Previous studies about antioxidant enzyme capacity in Lithodids were done in Paralomis granulosa (Romero et al. 2007, 2011), but they were focused on experiments of air exposure and re-submersion of those stone crabs. Particularly, the aim of the present study was to determine in both sexes of 2 lithodid species from South Atlantic, Lithodes santolla and L. confundens, the baseline status of antioxidant enzyme activities and lipid peroxidation levels. This approach could be useful to show the differential capability of each king crab species to deal with xenobiotics, and to understand their differential distribution pattern along the Atlantic continental shelfwaters.

\section{Materials ANd Methods}

\section{Animals}

A total of 45 adult animals of Lithodes spp. were caught in the Atlantic coast (Fig. 1) with an epibenthic trawl (Table 1 ), on board the RV Puerto Deseado, during the CONCACEN survey in December 2009. Crabs were sexed on the basis of the shape of their abdomens and presence of pleopods, and female condition recorded (presence of eggs or postovigerous setae). Carapace lengths (CL) were measured with a dial calliper with $0.1 \mathrm{~mm}$ precision. Then, animals were dissected by removing the carapace. The $7^{\text {th }}$ gill, the hepatopancreas and the muscular mass from the $4^{\text {th }}$ pair of pereiopods were dissected and frozen until analysis. All females employed were in postovigerous condition.

\section{SAMPLE PREPARATION}

Homogenates were prepared using $0.3 \mathrm{~g}$ of gills or $0.1 \mathrm{~g}$ of muscles or hepatopancreas tissue in 1.2 or $1.4 \mathrm{ml}$ of 


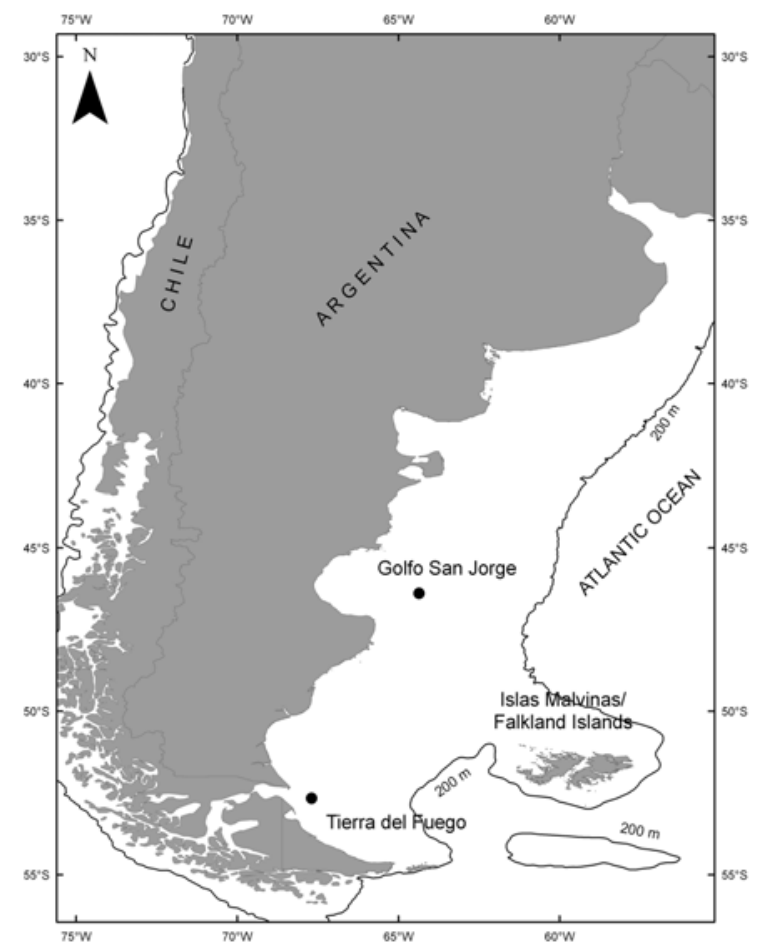

Figure 1. Sampling locations where Lithodes species were collected, on board the RV Puerto Deseado, during the CONCACEN survey in December $\mathbf{2 0 0 9}$ / Localidades de muestreo donde las especies de Lithodes fueron recolectadas, a bordo del RV Puerto Deseado durante la campaña CONCACEN en diciembre 2009

cold $\left(4^{\circ} \mathrm{C}\right)$ Tris-HCl buffer (0.125 M, pH 6.8), respectively. Samples were processed using a Teflon-glass homogenizer, and immediately centrifuged for $15 \mathrm{~min}$ at $11,000 \times \mathrm{g}$ at $4^{\circ} \mathrm{C}$. The supernatants were collected and employed as antioxidant enzyme source and for lipid peroxidation analysis.

\section{BIOCHEMICAL ANALYSES}

Specific enzyme activity was calculated considering the total protein content of the supernatant; results were expressed as enzyme units/mg of protein. Catalase (CAT) activity was measured by the method of Aebi (1984). The reaction mixture contained $50 \mathrm{mM}$ phosphate buffer $(\mathrm{pH}$ 7.0) and $3 \mathrm{mM} \mathrm{H}_{2} \mathrm{O}_{2}$, and it was registered spectrophotometrically at $240 \mathrm{~nm}$. One unit of CAT was defined as 1 pmol of $\mathrm{H}_{2} \mathrm{O}_{2}$ degraded per minute per milligram of protein.

Glutathione S-transferase (GST) was determined by the method of Habig et al. (1974). GST activity was measured by increasing in absorbance at $340 \mathrm{~nm}$, using reduced glutathione (GSH) and 1-chloro-2, 4-dinitrobenzene (CDNB) as substrates. The reaction mixture contained 0.1 M phosphate buffer (pH 6.5), 1 mM GSH and 1 mM CDNB. One unit was defined as $1 \mu \mathrm{mol}$ of GSH conjugated per min per mg of protein.

Lipid peroxidation (LPO) level was measured by the formation of thiobarbituric acid reactive substances (TBARS), according to Ohkawa et al. (1979). Homogenates were added to the reaction mixture (trichloroacetic acid 15\% (w/v), 2-thiobarbituric acid $0.375 \%(\mathrm{w} / \mathrm{v})$, clorhidric acid $0.25 \mathrm{~N}$ and butylhydroxytoluene $0.147 \mathrm{mM})$ in a ratio of 1:5 (v/v). The mixture was vigorously shaken, maintained in boiling water for $60 \mathrm{~min}$, and immediately cooled at $5^{\circ} \mathrm{C}$ for $5 \mathrm{~min}$. Then it was centrifuged at $5,000 \times \mathrm{g}$ for $10 \mathrm{~min}$, and the absorbance in the supernatant was measured spectrophotometrically at $535 \mathrm{~nm}$. TBARS concentration was expressed as $\mu \mathrm{mol}$ per $\mathrm{g}$ of wet tissue.

Total protein content of homogenates was determined following the method of Lowry et al. (1951), using bovine serum albumin as standard.

\section{Statistical ANALYSES}

The parameters considered were shown as mean \pm standard error. In order to determine the effects of both species and sexes on antioxidant enzyme activities and lipid peroxidation analyses of variance (two-way ANOVA) were performed. Significant differences at the 0.05 level were considered for this analysis. Data were checked for normality and homogeneity of variance by Kolmogorov-

Table 1. Sampling locations, sample size and carapace size of Lithodes spp. used in this study / Lugares de muestreo, tamaño de la muestra y tamaño del caparazón de los ejemplares de Lithodes spp. utilizados en este estudio

\begin{tabular}{|c|c|c|c|c|c|c|}
\hline Species & Lat (S); Long (W) & Location & Depth $(\mathrm{m})$, Temp $\left({ }^{\circ} \mathrm{C}\right)$ & Sex & $\mathrm{N}$ & LC (mm) \\
\hline \multirow[t]{2}{*}{ Lithodes santolla } & $46^{\circ} 23.5^{\prime} ; 64^{\circ} 21.3^{\prime}$ & San Jorge Gulf & $100 \mathrm{~m}, 8.01^{\circ} \mathrm{C}$ & Males & 12 & $120.51 \pm 11.57$ \\
\hline & & & & Females & 10 & $79.50 \pm 9.17$ \\
\hline \multirow[t]{2}{*}{ Lithodes confundens } & $52^{\circ} 39.5^{\circ} ; 67^{\circ} 41.1^{\prime}$ & Atlantic coast of Tierra del Fuego & $53 \mathrm{~m}, 6.30^{\circ} \mathrm{C}$ & Males & 11 & $121.19 \pm 14.06$ \\
\hline & & & & Females & 12 & $95.56 \pm 14.83$ \\
\hline
\end{tabular}




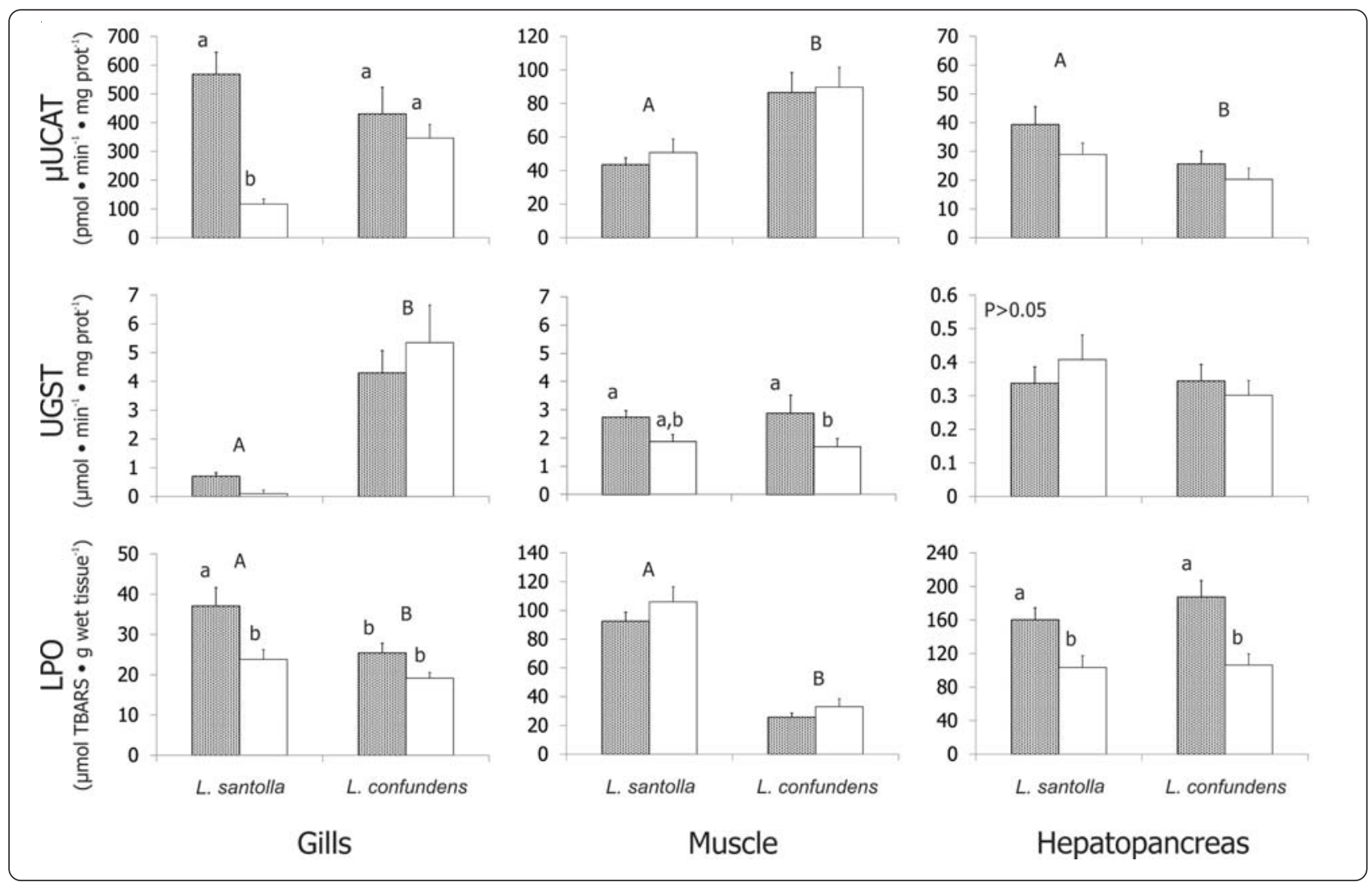

Figure 2. Mean \pm standard error of antioxidant enzyme activities of CAT (catalase), GST (glutathione S-transferase) and LPO (lipid peroxidation) in different organs of both lithodid species. Full and empty bars represent males and females, respectively. Different capital and small letters indicate significant differences between species (ANOVAs test), and sexes, respectively / Media \pm error estándar de la actividad enzimática antioxidante de CAT (catalasa), GST (glutatión S-transferasa) y LPO (peroxidación de lípidos) en diferentes órganos de ambas especies de litódidos. Barras llenas y vacías representan machos y hembras, respectivamente. Diferentes letras mayúsculas y minúsculas indican diferencias significativas entre especies (pruebas de ANDEVAs) y sexos, respectivamente

Smirnov and Levene tests, respectively (Sokal \& Rohlf 1995).

\section{Results}

Both species showed antioxidant enzyme activities. CAT activity for Lithodes spp. was highest in gills (Fig. 2). Significant differences in this antioxidant enzyme between species were found in muscle (where $L$. confundes presented a higher activity) and hepatopancreas (where L. santolla presented a higher activity, Fig. 2, Table 2). Furthermore, $L$. confundes presented similar CAT activity between sexes in gills, muscle and hepatopancreas, whereas $L$. santolla showed similar CAT activity between sexes only in muscle and hepatopancreas (Fig. 2, Table 2). The statistical interaction between species and sexes found in gills showed that CAT activity in female $L$. santolla was lowest in gills (Fig. 2, Table 2).
GST activity in gills varied between species but not between sexes. Values of GST activity of Lithodes confundes quadruplicated those registered in the other species (Fig. 2, Table 3). GST activity in the muscle only varied between sexes, where males presented significant higher activities than females (Fig. 2, Table 3). Moreover, the values of GST activity in the hepatopancreas were similar between species and sexes (Fig. 2, Table 3), and was on average $0.3 \pm 0.03 \mathrm{U} \mathrm{GST} \mathrm{mg} \mathrm{protein}^{-1}$.

Lipid peroxidation values were highest in the hepatopancreas of both Lithodes spp. (Fig. 2). The differences in this organ were found between sexes rather than species (Fig. 2, Table 4). Males presented lipid peroxidation values $\approx 60 \%$ higher than females (Fig. 2). Furthermore, lipid peroxidation in gills and muscles varied between species (Fig. 2). In both tissues Lithodes santolla showed significant higher values (Fig. 2, Table 4) than $L$. confundens. Particularly in muscle, where Lithodes 
Table 2. Results of the two-way ANOVAs (MS: mean squares, $F$ : stadigraph, $P$ : probability) to compare the effect of 2 species and sexes of Lithodes on the catalase activity (CAT) analysed in $\mathbf{3}$ organs / Resultados de los ANDEVAs de dos factores (MS: cuadrados medios, $F$ : estadígrafo, $P$ : probabilidad) para comparar el efecto de 2 especies y sexos de Lithodes en la actividad de la catalasa (CAT) analizada en 3 órganos

\begin{tabular}{lrrr}
\hline & \multicolumn{1}{c}{ MS } & \multicolumn{1}{c}{$F$} & \multicolumn{1}{c}{$P$} \\
\hline Gills & & & \\
$\quad$ Species & 30102 & 0.51 & 0.48 \\
Sexes & 878675 & 14.78 & $<<0.001$ \\
Species x Sexes & 421040 & 7.08 & 0.01 \\
Error & 59451 & & \\
Muscle & & & \\
$\quad$ Species & 14913.0 & 18.77 & $<<0.001$ \\
Sexes & 242.2 & 0.03 & 0.59 \\
Species x Sexes & 34.7 & 0.04 & 0.84 \\
Error & 794.4 & & \\
Hepatopancreas & & & \\
$\quad$ Species & 1082.60 & 5.61 & 0.02 \\
Sexes & 537.24 & 2.78 & 0.11 \\
$\quad$ Species x Sexes & 54.36 & 0.29 & 0.60 \\
Error & 192.96 & & \\
& & &
\end{tabular}

santolla presented lipid peroxidation values that almost triplicated those registered to L. confundens (Fig. 2).

\section{Discussion}

The present study provides baseline data on antioxidant defenses and lipid peroxidation in 2 king crab species during summer. Gills of Lithodes spp. were the organs that presented the highest CAT enzyme activities. This characteristic allows us to hypothesize that this organ has an important role in antioxidant defenses. In decapod crustaceans, gills are responsible for exchanging gases, highly functional in maintaining osmotic balance and have an important role in the immune response (Burnett et al. 2006 and references therein). Moreover, as oxygen diffuses through gill cells, this organ is exposed to higher oxygen concentrations compared to other tissues. Thus, the rate generation of ROS in gills is presumed to be higher (Maciel et al. 2004, Romero et al. 2011), and a higher protection level in this organ would be necessary to protect animals from oxidative stress. Therefore, the development of high levels of CAT activity seems to be the strategy used by gills to degrade $\mathrm{H}_{2} \mathrm{O}_{2}$ (Maciel et al. 2004), precursor of the highly reactive hydroxyl radical
(Hermes-Lima 2004). This important strategy used by CAT to remove $\mathrm{H}_{2} \mathrm{O}_{2}$ is employed by marine organisms against oxidative stress (see Giarratano et al. 2010). In fact, this pattern of high CAT activity in gills was found also in other decapods, as lithodids (the stone crab Paralomis granulosa, Romero et al. 2007, 2011), grapsids (the estuarine crab Neohelice granulata, Maciel et al. 2004), and penaeids (the shrimp Penaeus monodon, Tu et al. 2008), among others.

The enzyme glutathione-S-transferase (GST) is involved in the biotransformation of numerous xenobiotic compounds (Hermes-Lima 2004) using glutathione as substrate. Furthermore, GST protects cellular membranes from damage due to lipid peroxidation (see Tu et al. 2008). Particularly in gills of $L$. confundens, GST could be acting as another defense line (Fig. 2) since this enzyme displays a distinct GSH peroxidase activity and may play a protective role against oxidative stress when the activity of other antioxidant enzymes is lowered (Sheehan \& Power 1999). In fact, equilibrium between GST, CAT and GPx is important for the effective removal of ROS (see Tu et al. 2008).

Table 3. Results of the two-way ANOVAs (MS: mean squares, F: stadigraph, $P$ : probability) to compare the effect of 2 species and sexes of Lithodes on the glutathione-S-transferase activity (GST) analysed in $\mathbf{3}$ organs / Resultados de los ANDEVAs de dos factores (MS: cuadrados medios, F: estadígrafo, $P$ : probabilidad) para comparar el efecto de 2 especies y sexos de Lithodes en la actividad de la glutatión S-transferesa (GST) analizada en 3 órganos

\begin{tabular}{lrrr}
\hline Response variable & \multicolumn{1}{c}{ MS } & \multicolumn{1}{c}{$F$} & \multicolumn{1}{c}{$P$} \\
\hline Gills & & & \\
Species & 220.22 & 38.41 & $<<0.001$ \\
Sexes & 0.62 & 0.11 & 0.75 \\
Species x Sexes & 7.57 & 1.32 & 0.26 \\
Error & 5.73 & & \\
& & & \\
Muscle & & & \\
Species & 0.004 & 0.003 & 0.96 \\
Sexes & 9.48 & 6.33 & 0.02 \\
Species x Sexes & 0.23 & 0.15 & 0.70 \\
Error & 1.50 & & \\
& & & \\
Hepatopancreas & & & \\
Species & 0.03 & 0.83 & 0.37 \\
Sexes & 0.002 & 0.07 & 0.80 \\
Species x Sexes & 0.03 & 1.06 & 0.31 \\
Error & 0.03 & & \\
\hline
\end{tabular}


Table 4. Results of the two-way ANOVAs (MS: mean squares, F: stadigraph, P: probability) to compare the effect of 2 species and sexes of Lithodes on the lipid peroxidation activity (LPO) analysed in 3 organs / Resultados de los ANDEVAs de dos factores (MS: cuadrados medios, F: estadígrafo, P: probabilidad) para comparar el efecto de 2 especies y sexos de Lithodes en la actividad de la peroxidación de lípidos (LPO) analizada en 3 órganos

\begin{tabular}{lrrr}
\hline Response variable & \multicolumn{1}{c}{ MS } & \multicolumn{1}{l}{$F$} \\
\hline Gills & & & \\
Species & 832.49 & 6.28 & 0.02 \\
Sexes & 1068.03 & 8.05 & 0.01 \\
Species x Sexes & 161.48 & 1.22 & 0.28 \\
Error & 132.64 & & \\
Muscle & & & \\
Species & 57880.6 & 107.05 & $<<0.001$ \\
Sexes & 1272.8 & 2.34 & 0.13 \\
Species x Sexes & 112.6 & 0.21 & 0.65 \\
Error & 540.7 & & \\
& & & \\
Hepatopancreas & & & \\
Species & 2473.3 & 0.94 & 0.34 \\
Sexes & 52117.5 & 19.85 & $<<0.001$ \\
Species x Sexes & 1609.9 & 0.61 & 0.44 \\
Error & 2625.9 & & \\
\hline
\end{tabular}

In crustaceans the hepatopancreas represents the main organ involved in the biotransformation processes, redox cycle generation and antioxidant defenses (James \& Boyle 1998) due to the multiple oxidative reactions that take place therein (Arun \& Subramanian 1998). Since we did not observe high values of antioxidant enzyme activities in this tissue, we suggest 2 alternative possibilities. On the one hand, any other antioxidant enzymes not analyzed in this work, as SOD (Superoxide Dismutase) or GPX (Glutathione Peroxidase), might be involved as antioxidant defenses in the hepatopancreas and present there a key role. On the other hand, non-enzymatic antioxidants could also be acting in this organ. In fact, carotenoids and their derivatives, as $\beta$-carotene, were found in high concentration in the hepatopancreas of crustaceans (Sagi et al. 1995), and are known to deactivate chemical species such as singlet oxygen, triplet photochemical sensitizers, and free radicals (Miki 1991, Matsuno 2001).

Differences in the analysed parameters in this study between both species could be attributed to intrinsic adaptation features of each king crab species and/or environmental conditions of each particular study area (Table 1). For example, it is known that the dissolved oxygen in waters where adult L. santolla inhabit in the austral channels could be lower than 8.3 kPa (Guzmán \& Silva 2002), and that juveniles of this species showed a moderate tolerance to low oxygen availability (Paschke et al. 2010). But until now there are no data about environmental conditions where Lithodes confundens inhabit. Particularly, the slight difference in depth water temperature between both sampled areas (Table 1) could result in different enzymatic activities or LPO values in the species. In fact, water temperature differences of $2^{\circ} \mathrm{C}$ can generates differential oxygen consumption rates in the king crab Paralithodes platypus from Bearing sea (Romero et al. 2010).

In the present study, both determinations of activities of antioxidant enzymes and lipid peroxidation were done during austral summer and we suppose that were the maxima expected throughout the year long. During these months there is an increase of environmental light and sea water temperature and it is known that these both parameters induce oxidative stress. Particularly, temperature accelerates ROS formation in marine ectotherms simply by accelerating mithocondrial respiration (Freire et al. 2012). In the crayfish Procambarus clarkii light irradiance induces antioxidant activity increase to protect the animals from oxidative stress and further lipid and protein oxidation (FanjulMoles et al. 2003).

Southern lithodid crabs perform vertical migrations in austral summer to moult and mate in shallow waters (Lovrich \& Tapella 2013). However, the only representative of the family found in the intertidal during the spring ebb tides is Lithodes confundens (Lovrich et al. 2002). This behaviour could explain the differences found in the present study between both Lithodes spp. In $L$. confundens CAT and GST activities are significantly higher in muscle and gills respectively, whereas lipid peroxidation is significantly lower in both organs of this species. Hence, differences in the activity of antioxidant enzymes between both species suggest that $L$. confundens is more capable of dealing with oxidative stress situations due to a better battery of antioxidant defenses since this species experiment anoxia periods in the tides.

Most studies on oxidative stress have been done with animals previously acclimated, and hence the importance of this field study that may serve as a baseline. Both lithodid species here analyzed could be considered important from the economical, ecological and physiological point of view. On the one hand, they 
represent one of the most valuable crustacean species due to both their high yields and acceptance in the markets (Lovrich \& Tapella 2013). The large sizes of adults, the relative high abundance of both species (Lovrich \& Tapella 2013) along with their role as top predators in their respective communities (Thatje et al. 2005, FalkPetersen et al. 2011) make them an important link in food webs, similar to other decapods, e.g. the stone crab Paralomis granulosa in the San Jorge Gulf (Vinuesa 2005), the spiny lobster Panulirus argus in tropical and temperate seas (Lipcius \& Eggleston 2000), the red shrimp Aristeus antennatus and the Norway lobster Nephrops norvegicus in the Mediterranean sea (Antó et al. 2009). Finally, our results show that parameters as CAT, GST and lipid peroxidation could be proposed as biomarkers of oxidative stress to indicate the general stress status of Lithodid species. In fact, these parameters were successfully tested in the shrimp Penaeus monodon (Tu et al. 2008), in an amphipod Parmorea sp. (only for GST, Schvezov \& Amin 2011), in the mussel Mytilus chilensis (Giarratano et al. 2010) and in the crab Carcinus maenas (for GST, Rodrigues et al. 2012). Thus, from a physiological point of view, these both Lithodid species could be useful as biomarkers for biomonitoring studies linked to climate change and/or environmental pollution.

\section{ACKNOWLEDgments}

Authors are indebted to the captain and crew of the RV Puerto Deseado. This work was supported by CONICET (PIPs 0200 and 0335) and Agencia Nacional de Promoción Científica y Tecnológica (ANPCyT-PICT 1308). Two anonymous reviewers provided useful comments to improve the manuscript.

\section{LITERATURE CITED}

Aebi H. 1984. Catalase in vitro. Methods in Enzymology 105: 121-126.

Antó M, S Arnau, E Buti, V Cortijo, E Gutierrez \& M Solé. 2009. Characterisation of integrated stress biomarkers in two deep-sea crustaceans, Aristeus antennatus and Nephrops norvegicus, from the NW fishing grounds of the Mediterranean sea. Ecotoxicology and Environmental Safety 72: $1455-1462$.

Arun S \& P Subramanian. 1998. Antioxidant enzymes in freshwater prawn Macrobrachium malcolmsonii during embryonic and larval development. Comparative Biochemistry and Physiology 121 B: 273-277.

Burnett LE, JD Holman, DD Jorgensen, JL Ikerd \& KG Burnett. 2006. Immune defense reduces respiratory fitness in Callinectes sapidus, the Atlantic blue crab. Biology Bulletin 211: 50-57.
Correia AD, MH Costa, OJ Luis \& DR Livingstone. 2003. Age-related changes in antioxidant enzyme activities, fatty acid composition and lipid peroxidation in whole body Gammarus locusta (Crustacea: Amphipoda). Journal of Experimental Marine Biology and Ecology 289: 83-101.

Dutra BK, RB Santos, AAP Bueno \& GT Oliveira. 2008. Seasonal variations in the biochemical composition and lipoperoxidation of Hyalella curvispina (Crustacea, Amphipoda). Comparative Biochemistry and Physiology 151 A: 322-328.

Eburne RC \& G Prentice. 1996. Modified atmosphere packed ready to cook and ready to eat meat products. In: Man CMD \& AA Jones (eds). Shelf life evaluation of foods, pp. 156-178. Chapman \& Hall, Suffolk.

Falk-Petersen J, P Renaud \& N Anisimova. 2011. Establishment and ecosystem effects of the alien invasive red king crab (Paralithodes camtschaticus) in the Barents Sea-a review. ICES Journal of Marine Science 68: 479-488.

Fanjul-Moles ML, ME Durán-Lizarraga, ME Gonsebatt \& J Prieto-Sagredo. 2003. The effect of photoperiod and light irradiance on the antioxidant circadian system of two species of crayfish from different latitudes: Procambarus clarkii and P. digueti. Photochemistry and Photobiology 77: 210-218.

Freire CA, AF Welker, JM Storey, KB Storey \& M HermesLima. 2012. Oxidative stress in estuarine and intertidal environments (temperate and tropical). In: Abele D, JP Vazquez-Medina \& T Zenteno-Savin (eds). Oxidative stress in aquatic ecosystems 3: 41-57. Wiley, Blackwell.

Giarratano E, CA Duarte \& OA Amin. 2010. Biomarkers and heavy metal bioaccumulation in mussels transplanted to coastal waters of the Beagle Channel. Ecotoxicology and Environmental Safety 73: 270-279.

Guzmán D \& N Silva. 2002. Caracterización física y química y masas de agua en los canales australes de Chile entre Boca del Guafo y Golfo Elefantes (Crucero CIMAR Fiordo 4). Ciencia y Tecnología del Mar 25: 45-76.

Habig WH, MJ Pabst \& WB Jakoby. 1974. Glutathione Stransferases. The first step in marcapturic acid formation. Journal of Biological Chemistry 249: 7130-7139.

Halliwell B \& JMC Gutteridge. 1999. Free radicals, other reactive species and disease. In: Halliwell B \& JMC Gutteridge (eds). Free radicals in biology and medicine, pp. 617-783. Clarendon Press, Oxford.

Hermes-Lima M. 2004. Oxygen in biology and biochemistry: role of free radicals. In: Storey KB (ed). Functional metabolism: Regulation and adaptation, pp. 319-368. John Wiley \& Sons, Hoboken.

James MO \& SM Boyle. 1998. Cytochrome P450 in Crustacea. Comparative Biochemistry and Physiology 121C: 157-172.

Leaver MJ \& SG George. 1998. A piscine glutathione Stransferase which efficiently conjugates the end-products of lipid peroxidation. Marine Environmental Research 46: 1-5. 
Lipcius RN \& DB Eggleston. 2000. Ecology and fishery biology of spiny lobsters. In: Phillips B \& J Kittaka (eds). Spiny lobsters: Fisheries and culture, pp. 1-41. Blackwell Scientific Publications, Oxford.

Lovrich GA \& F Tapella. 2013. Southern king crabs. In: Stevens B (ed). King crabs of the world: Biology and fisheries management. CRC Press, Taylor \& Francis Group, Boca Raton. [Preview-In Press]

Lovrich GA, M Perroni, JH Vinuesa, F Tapella, AC Chizzini \& MC Romero. 2002. Occurrence of Lithodes confundens (Decapoda: Anomura) in the intertidal of the Southwestern Atlantic. Journal of Crustacean Biology 22: 894-902.

Lowry OH, NJ Rosenbrough, AL Farr \& RJ Randall. 1951. Protein measurement with the Folin phenol reagent. Journal of Biological Chemistry 193: 265-275.

Maciel FE, CE Rosa, EA Santos, JM Monserrat \& LEM Nery. 2004. Daily variations in oxygen consumption, antioxidant defenses, and lipid peroxidation in the gills and hepatopancreas of an estuarine crab. Canadian Journal of Zoology 82: 1871-1877.

Macpherson E. 1988. Revision of the family Lithodidae Samouelle, 1819 (Crustacea, Decapoda, Anomura) in the Atlantic Ocean. Monografías de Zoología Marina 2: 9-153.

Matsuno T. 2001. Aquatic animal carotenoids. Review article. Fisheries Science 67: 771-783.

Miki W. 1991. Biological functions and activities of animal carotenoids. Pure and Applied Chemistry 63: 141-146.

Ohkawa H, N Ohishi \& K Yagi. 1979. Asssay of lipid peroxides in animal tissues by thiobarbituric acid reaction. Analytical Biochemistry 95: 351-358.

Paschke K, JP Cumillaf, S Loyola, P Gebauer, M Urbina, ME Chimal, C Pascual \& C Rosas. 2010. Effect of dissolved oxygen level on respiratory metabolism, nutritional physiology, and immune condition of southern king crab Lithodes santolla (Molina, 1782) (Decapoda, Lithodidae). Marine Biology 157: 7-18.

Rodrigues AP, PC Oliveira, L Guilhermino \& L Guimarães. 2012. Effects of salinity stress on neurotransmission, energy metabolism and anti-oxidant biomarkers of Carcinus maenas from two estuaries of the NW Iberian Peninsula. Marine Biology 159: 2061-2074.

Romero MC, M Ansaldo \& GA Lovrich. 2007. Effect of aerial exposure on the antioxidant status in the subantarctic stone crab Paralomis granulosa (Decapoda: Anomura). Comparative Biochemical Physiology 146 C: 54-59.
Romero MC, F Tapella, GB Stevens \& CL Buck. 2010. Effects of reproductive stage and temperature on rates of oxygen consumption in Paralithodes platypus (Crustacea: Decapoda: Anomura). Journal of Crustacean Biology 30: 393-400.

Romero MC, F Tapella, MP Sotelano, M Ansaldo \& GA Lovrich. 2011. Oxidative stress in the subantarctic stone crab Paralomis granulosa during air exposure and subsequent re-submersion. Aquaculture 319: 205-210.

Sagi A, M Rise, K Isam \& S Arad. 1995. Carotenoids and their derivatives in organs of the maturating female crayfish Cherax quadricarinatus. Comparative Biochemical Physiology 112 B: 309-313.

Schvezov N \& OA Amin. 2011. Biochemical response of amphipods (Gammarid: Paramorea) in a sediment laboratory exposure from Ushuaia Bay, Beagle Channel. Ecotoxicology and Environmental Safety 74: 394-402.

Sheehan D \& A Power A. 1999. Effects of seasonality on xenobiotic and antioxidant defence mechanisms of bivalve molluscs. Comparative Biochemical Physiology 123 C: 193-199.

Sokal RR \& FJ Rohlf. 1995. Biometry. The principles and practice of statistics in biological research, pp. 1-887. W.H. Freeman and Co, New York.

Sotelano MP, MF Gowland-Sainz, MJ Diez \& GA Lovrich. 2013. Distribution of Lithodes confundens Macpherson, 1988 (Decapoda, Anomura) along the Atlantic continental shelf of southern South America. Crustaceana 86: 246-252.

Thatje S, K Anger, JA Calcagno, GA Lovrich, HO Pörtner \& WE Arntz. 2005. Challenging the cold: crabs reconquer the Antarctic. Ecology 86: 619-625.

Tu HT, F Silvestre, A Bernard, C Douny, NT Phuong, CT Tao, G Maghuin-Rogister \& P Kestemont. 2008. Oxidative stress response of black tiger shrimp (Penaeus monodon) to enrofloxacin and to culture system. Aquaculture 285: 244-248.

Vinuesa JH. 1991. Biología y pesquería de la centolla (Lithodes santolla). Atlantica, Rio Grande 13: 233-244.

Vinuesa JH. 2005. Distribución de crustáceos decápodos y estomatópodos del golfo San Jorge, Argentina. Revista de Biología Marina y Oceanografía 40: 7-21.

Received 31 October 2012 and accepted 18 April 2013

Associate Editor: Gabriela Muñoz C. 